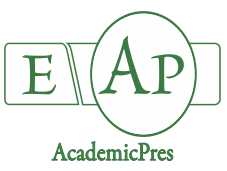

Khan I et al. (2021)

Notulae Botanicae Horti Agrobotanici Cluj-Napoca

Volume 49, Issue 2, Article number 12303

DOI: $10.15835 /$ nbha 49212303

Research Article

\title{
Enhancing antioxidant defense system of mung bean with a salicylic acid exogenous application to mitigate cadmium toxicity
}

\author{
Imran KHAN ${ }^{1}$, Mahmoud F. SELEIMAN ${ }^{2,3 *}$, Muhammad U. \\ CHATTHA $^{1}$, Rewaa S. JALAL ${ }^{4}$, Faisal MAHMOOD ${ }^{5}$, \\ Fahmy A.S. HASSAN ${ }^{6}$, Warda IZZET ${ }^{7}$, Bushra A. ALHAMMAD ${ }^{8}$, \\ Esmat F. ALI ${ }^{6}$, Rana ROY ${ }^{9}$, Omer S. USLU ${ }^{10}$, Muhammad U. HASSAN ${ }^{1}$ \\ ${ }^{1}$ University of Agriculture Faisalabad, Department of Agronomy, Faisalabad, 38040, Pakistan; drimran@uaf.edu.pk; \\ drumer@uaf.edu.pk;muhassanuaf@gmail.com \\ ${ }^{2}$ King Saud University, College of Food and Agriculture Sciences, Plant Production Department, P.O. Box 2460, Riyadh 11451, \\ SaudiArabia; mseleiman@ksu.edu.sa (*corresponding author); \\ ${ }^{3}$ Menoufia University, Faculty of Agriculture, Department of Crop Sciences, Shibin El-kom 32514, Egypt; \\ mahmoud.seleiman@agr.menofia.edu.eg \\ ${ }^{4}$ University of Jeddah, College of Sciences, Department of Biology,Jeddah, Saudi Arabia; rsjalal@uj.edu.sa \\ ${ }^{5}$ Government College University Faisalabad, Department of Environmental Sciences \& Engineering, Faisalabad, Pakistan; \\ fslagronomy@hotmail.com \\ ${ }^{6}$ Taif University, College of Science, Department of Biology, P.O. Box 11099, Taif 21944, Saudi Arabia; d.fahmy@tu.edu.sa; \\ a.esmat@tu.edu.sa \\ ${ }^{7}$ University of Agriculture Faisalabad, Department of Botany, Faisalabad, 38040, Pakistan; wardaizzet@gmail.com \\ ${ }^{8}$ Prince Sattam Bin Abdulaziz University, College of Science and Humanity Studies, Biology Department, Al Kharj Box 292, Riyadh \\ 11942, Saudi Arabia; b.alhammad@psau.edu.sa \\ ${ }^{9}$ Sylhet Agricultural University, Faculty of Agriculture, Department of Agroforestry \& Environmental Science, Sylhet 3100 , \\ Bangladesh; ranaroy.aes@sau.ac.bd \\ ${ }^{10}$ University of Sutcu Imam, Faculty of Agriculture, Department of Field Crops, Turkey; suhauslu@ksu.edu.tr
}

\begin{abstract}
Cadmium $(\mathrm{Cd})$ accumulation is an emerging environmental hazard and has detrimental effects on plant growth and development. Salicylic acid (SA) is a well-known plant growth regulator that can initiate various molecular pathways to ameliorate $\mathrm{Cd}$ toxicity. The experiment was executed to scrutinize the mediatory role of SA to accelerate the defensive mechanism of mung bean in response to $\mathrm{Cd}$ stress. Mung bean plants were exposed to $0,5,10$ and $15 \mathrm{mg} \mathrm{Cd} \mathrm{kg}^{-1}$ of soil. Exogenous application of $\mathrm{SA} 0,10^{-6}$ and $10^{-3} \mathrm{M}$ was added prior flowering. Results exhibited that $\mathrm{Cd}$ stress considerably reduced the growth-related attributes i.e. shoot length, root length, fresh and dry biomass, total soluble protein, total amino acids, relative water contents and photosynthetic pigments. Cadmium stress showed a significant increase in antioxidants levels such as peroxidase (POD), ascorbate peroxidase (APX), ascorbic acid (AsA), and catalase (CAT) and promoted the accumulation of hydrogen peroxide $\left(\mathrm{H}_{2} \mathrm{O}_{2}\right)$ and malondialdehyde (MDA) contents. However, exogenously applied SA significantly improved plant biomass and photosynthetic pigments under $\mathrm{Cd}$ stress. Moreover, $\mathrm{SA}$ improved the defensive system by enhancing antioxidants' activities under the increasing concentration of Cd stress. Furthermore, $\mathrm{SA}$ reduced the $\mathrm{Cd}$ uptake, membrane damage and, $\mathrm{H}_{2} \mathrm{O}_{2}$ and MDA accumulation. The

Received: 05 Mar 2021. Received in revised form: 26 Mar 2021. Accepted: 12 Apr 2020. Published online: 11 May 2021.

From Volume 49, Issue 1, 2021, Notulae Botanicae Horti Agrobotanici Cluj-Napoca journal uses article numbers in place of the traditional method of continuous pagination through the volume. The journal will continue to appear quarterly, as before, with four annual numbers.
\end{abstract}


study's findings concluded that exogenous-applied SA enhanced plant growth, promoted the antioxidant activities, and reduced the oxidative damage in mung bean seedlings under $\mathrm{Cd}$ stress.

Keywords: antioxidant machinery; heavy metal stress; mung bean; photosynthesis; reactive oxygen species; salicylic acid

\section{Introduction}

The natural environment has frequently acquiring metal pollution from the anthropogenic fonts comprising sewage expulsions, mining manoeuvres, phosphate fertilizers and overflows from metal refining industries and other industries (Yang et al., 2006; Liu et al., 2007; Seleiman et al., 2012; Seleiman et al., 2013; Seleiman et al., 2017; Hassan et al., 2019; Seleiman et al., 2020a; Seleiman et al., 2020b; Hassan et al., 2021; Seleiman et al., 2021a). World health organization categorized the heavy metals pollution as the second most adverse pollution because it has severe threats to human health (Salem et al., 2018). Cadmium is a non-essential heavy metal, readily absorbs by plants that have perilous outcomes on plant growth and confines the crop yield and it also has toxic effects on humans (Yang et al., 2004; Abbas et al., 2017; Aamer et al., 2018; Saleem et al., 2019; Rasheed et al., 2020). Cd is noxious to the plant cell, even at a very minute concentration in leaf greater than 5-10 $\mu \mathrm{g} \mathrm{g}^{-1}$ has lethal effects on most plant species (White and Brown, 2010). Furthermore, Cd has damaging effects on the plant metabolism resulting in growth retardation, reducing nutrient uptake, leaf chlorosis and necrosis (Xue et al., 2013), ionic unbalancing, inhibit the stomatal opening and reduce the biomass production (Barceló and Poschenrieder, 1990; Seleiman et al., 2020c).

The efficiency of the photosynthetic system is highly affected due to Cd-induced stress (Vassilev et al., 2005; Ekmekçi et al., 2008) that is affiliated with the inhibition of chlorophyll biosynthesis as well as an alteration in the oxidizing site of PS II. Cd stress degrades the normal functioning of the Calvin cycle by inhibiting the activity of RuBP (Krantev et al., 2008) and degrades the ultra-structure of chloroplast and mitochondria (Šimonová et al., 2007). Cd induces oxidative impairment by assembling the reactive oxygen species (ROS) comprising free hydroxyl ions $\left(\mathrm{OH}^{-}\right)$and super oxide radicals $\left(\mathrm{O}_{2}{ }^{-}\right)$(Hendry et al., 1992) and thereby reduces the membrane stability and increases the degradation of macromolecules DNA, RNA and protein. It is usually recognized that oxidative mutilation in plants is controlled by the antioxidants (Acar et al., 2001; Türkan et al., 2005). Plants have a scavenging mechanism including enzymatic (i.e. POD, SOD, APX and CAT) and non-enzymatic antioxidants (i.e. anthocyanin and ascorbic acid) against different stress conditions (Al-Ashkar et al., 2020; Hassan et al., 2020; Seleiman et al., 2021a; Seleiman et al., 2021b). They protect the plants from different abiotic stresses, but their activity is reduced due to metal ion interaction (Noriega et al., 2012, Sofy et al., 2020).

Nowadays, different hormones are extensively employed to minimize the effect of abiotic and biotic stresses. Salicylic acid is one of the naturally existing signalling molecules and a good hormone for improving plant tolerance counter to diverse biotic and abiotic stresses (Hayat et al., 2010; Hafez et al., 2017). Exogenous application of SA could alleviate the Cd lethality in various crops including barley, maize, soya bean, and wheat. Some organic components and SA promote many physiological processes such as seed germination, flower induction uptake of mineral nutrition and biosynthesis of photosynthetic pigments (Klessing, 2017; Sofy et al., 2020; Uslu et al., 2020). Salicylic acid has a multifaceted role in all metabolic processes most actively involved in regulating enzymatic and non-enzymatic biomolecules under environmental stresses. It has an excellent ability to develop defensive coordination with enzymatic antioxidants. Moreover, it can also produce some non-enzymatic plant products in cellular and subcellular compartments of plant cell to compete with the reactive oxygen species (Singh and Gautam, 2013). SA can inflect the plant response to an inclusive array of oxidative stress by modulating the redox balance, antioxidant responses and scavenging the accumulation of reactive oxygen species (Shi and Zhu, 2008). It has been reported that SA also involves in the regulation of 
membrane fluidity, uncoupling the mitochondrial electron transport chain by the activation of glutathione reductase and guaiacol peroxidase (Shao et al., 2010).

Mung bean is a short-duration, drought-tolerant, a leguminous crop with many effective uses and of great economic importance. It is a rich source of protein and also improves soil fertility (Elahi et al., 2004). Therefore, it is highly valuable and sustainable crop across the globe. But it is susceptible to Cd stress (Wahid et al., 2008) and no detailed study was carried out on mung bean against $\mathrm{Cd}$ toxicity with exogenous application of SA.

Hence, the current study was executed to explore the ameliorative role of $S A\left(10^{-6} \mathrm{M}\right.$ and $\left.10^{-3} \mathrm{M}\right)$ on growth, physiochemical mechanisms, and antioxidant system activities in mung bean (Vigna radiata L.) grown under Cd stress $\left(0,5,10\right.$ and $15 \mathrm{mg} \mathrm{Cd} \mathrm{kg}^{-1}$ of soil).

\section{Materials and Methods}

\section{The site and experimental design}

The trial was directed to regulate the influence of exogenous-applied salicylic acid on mung bean crop against Cd stress. A pot experiment was conducted at Department of Agronomy, University of Agriculture, Faisalabad. The semiarid climate was prevailed in Faisalabad with a maximum temperature of $36.1{ }^{\circ} \mathrm{C}$ and minimum temperature of $20.2^{\circ} \mathrm{C}$, rain fall occurrence of $40 \mathrm{~mm}$, and relative humidity of $41.6 \%$ during the period of March- May 2018. The experiment was placed in a completely randomized design (CRD) with factorial arrangement having four replications.

\section{Treatments}

The soil was spiked with diverse cadmium concentrations, i.e. $0,5,10$ and $15 \mathrm{mg} \mathrm{Cd} \mathrm{kg}^{-1}$ of soil, and left for seven days to equilibrate before sowing. Cadmium chloride $\mathrm{CdCl}_{2}$ (Sigma Aldrich) was used as the source of cadmium. Two salicylic acid concentrations $10^{-6} \mathrm{M}$ and $10^{-3} \mathrm{M}$ were exogenous sprayed while distilling water spray was used as control. The soil analysis is presented in Table (1).

Table 1. Physiochemical properties of experimental soil

\begin{tabular}{|l|c|c|}
\hline \multicolumn{1}{|c|}{ Characteristics } & Value & Unit \\
\hline Textural class & Clay loam & - \\
\hline EC & 1.82 & $\%$ \\
\hline Organic matter & 0.64 & - \\
\hline pH & 7.8 & $\%$ \\
\hline Clay & 33.4 & $\%$ \\
\hline Sand & 26.4 & $\%$ \\
\hline Silt & 41.1 & $\%$ \\
\hline
\end{tabular}

\section{Planting material and crop management}

Seeds of Mung bean cultivar (NIAB, 2016) were obtained from Nuclear Institute for Agriculture \& Biology (NIAB), Faisalabad. Healthy seeds of the same size were purified with a $5 \%$ solution of $\mathrm{NaClO}$ for 10 min then washed with distilled water three times. The soil was obtained from 1 to $10 \mathrm{~cm}$ depth with $1: 1$ sand and silt composition. The soil samples' physiochemical properties were determined as described by Oweis et al. (1999), (Table 1). Soil samples were also subjected to analyze the cumulated heavy metals however, no heavy metals including $\mathrm{Cd}$ was found. Plastic pots having a diameter of $24 \mathrm{~cm}$ and holes in the bottom for a proper drainage were used in the current study. Each pot was filled with $7 \mathrm{~kg}$ of soil. Ten seeds of mung bean were sown in each pot, and thinning was done after emergence to maintain 6 seedlings per pot. The recommended dosage of sulfate of potash (SOP; $3.73 \mathrm{~g}$ ) and diammonium phosphate (DAP; $7.44 \mathrm{~g}$ ) was applied at the time 
of sowing, irrigation was applied when needed. Remaining all the management practices were kept constant in all the pots.

\section{Plant sampling}

Mung bean plants were sampled after ten days of exogenous-applied SA for determination of various growth and physio-chemical parameters. Three plants from each pot were selected to determine the shoot and root fresh weight along with their root and shoot length as well as number of leaves. The same plant samples were dried to determine the root and shoot dry weight. The dried samples were crushed and grounded into a powder to be used for $\mathrm{Cd}$ analysis. Likewise, three plants were selected from each pot and reserved at $-20^{\circ} \mathrm{C}$ for the analysis of diverse physiochemical attributes.

\section{Determination of photosynthetic pigments}

Chlorophyll "a" and "b" were resolved by the method of Arnon (1949). A fresh composite sample of plant leaves $(0.25 \mathrm{~g})$ was finely chopped into small sections and dipped into $2.5 \mathrm{~mL}$ of $80 \%$ methanol, and left $24 \mathrm{~h}$ at room temperature. The absorbance of sample was noted at OD 645 and OD $663 \mathrm{~nm}$. The final value of chlorophyll ' $a$ ' and ' $b$ ' was deliberated by the following subsequent formula:

$$
\begin{aligned}
& \text { chlorophyll } a=((12.7(\text { OD 663 })-2.69(\text { OD 645) }) \times V / 1000 \times W \\
& \text { chlorophyll } b=((22.9(\text { OD } 645-4.68(\text { OD } 663)) \times V / 1000 \times W
\end{aligned}
$$

$\mathrm{V}=$ volume of methanol $(\mathrm{mL}) ; \mathrm{W}=$ plant sample's weight.

\section{Determination of electrolyte leakage}

A fresh sample of plant leaves $(0.3 \mathrm{~g})$ was added to a glass tube and dipped with $20 \mathrm{~mL}$ of distilled water. Tubes were retained at room temperature for three $h$ then assayed for $\mathrm{EC}_{1}$ using an $\mathrm{EC}$ meter. The same samples were left for $24 \mathrm{~h}$ and then placed in a boiler for $50 \mathrm{~min}$ at $90^{\circ} \mathrm{C}$ and analyzed for $\mathrm{EC}_{2}$ (Yan et al., 1996). The ultimate value of electrolyte leakage was determined via the following formula:

$$
E C \%=\left(\frac{E C 1}{E C 2}\right) \times 100
$$

\section{Determination of $R W C$}

Relative water contents were measured by the technique of Turner (1981). Fresh leaves of equal size were plucked and their fresh weight $(\mathrm{FW})$ was calculated. Afterwards, leaves were dipped in distilled water and left over for a night and their turgid weight (TW) was determined. The same leaf samples were dehydrated in an oven at $90^{\circ} \mathrm{C}$ for $2 \mathrm{~h}$ to determine the dry weight (DW), and finally the RWC was evaluated by given below formula:

$$
R W C \%=(F W-D W \div T W-D W) \times 100
$$

\section{Determination of soluble protein}

Soluble protein in the cell was examined by the technique of Bradford (1976). Leaf sample (0.5 g) was grounded under cold condition by adding $5 \mathrm{~mL}$ of potassium phosphate buffer $(50 \mathrm{mM})$ then centrifuged at $15,000 \mathrm{rpm}$ at $4{ }^{\circ} \mathrm{C}$. The supernatant was collected in a glass tube and $3 \mathrm{~mL}$ of Bradford reagent was poured in the tube and left for $15 \mathrm{~min}$ at $37^{\circ} \mathrm{C}$. The absorbance was checked at wavelength $595 \mathrm{~nm}$ by using a spectrophotometer (Model 6305, Jenway, Staffordshire, United Kingdom).

\section{Determination of free amino acid}

Moore and Stein (1954) technique was used to analyze the free amino acid in the plant cell. The leaf sample $(0.5 \mathrm{~g})$ was homogenized by adding $5 \mathrm{~mL}$ of potassium phosphate buffer $(50 \mathrm{mM})$. The plant extract was separated at $15,000 \mathrm{rpm}$ at $4{ }^{\circ} \mathrm{C}$ and plant extract was treated with one $\mathrm{mL}$ of $2 \%$ ninhydrin and one $\mathrm{mL}$ of $10 \%$ pyridine in a glass tube. Then tubes containing the mixture was heated at $90{ }^{\circ} \mathrm{C}$ for $30 \mathrm{~min}$. After 
heating distilled water was added to these test tubes and maintained volume up to $20 \mathrm{~mL}$. The absorbance was determined at $570 \mathrm{~nm}$ by using a spectrophotometer.

\section{Determination of hydrogen peroxide}

$\mathrm{H}_{2} \mathrm{O}_{2}$ content was examined by the technique of Velikova et al. (2000). A fresh leaf sample $(0.5 \mathrm{~g})$ was standardized in $5 \mathrm{~mL}$ of $5 \%$ trichloroacetic acid. Then centrifuged the crud at $10,000 \mathrm{rpm}$ for $15 \mathrm{~min}$ at $4{ }^{\circ} \mathrm{C}$, one $\mathrm{mL}$ of supernatant, one $\mathrm{mL}$ of $1 \mathrm{M} \mathrm{KI}$, and $100 \mu \mathrm{l}$ of potassium phosphate buffer was poured in a test tube and hydrogen peroxide content was checked at $390 \mathrm{~nm}$ on a spectrophotometer.

\section{Determination of $M D A$}

Malondialdehyde was scrutinized by the scheme of Cakmak and Horst (1991). The plant sample $(0.5$ g) was finely grounded in $5 \mathrm{~mL}$ of $5 \%$ TCA to get the supernatant under cold conditions. Then, one $\mathrm{mL}$ of supernatant, one $\mathrm{mL}$ of $0.5 \% \mathrm{TCA}$, and one $\mathrm{mL}$ of $20 \% \mathrm{TBA}$ (thiobarbituric acid) was mixed in the test tube and sited tubes in the water bath at $90^{\circ} \mathrm{C}$ for $30 \mathrm{~min}$. The malondialdehyde was figured out at a wavelength of $532 \mathrm{~nm}$ and $600 \mathrm{~nm}$ via a spectrophotometer.

\section{Activity of antioxidants}

The activity of CAT and POD was examined as described by Chance and Maehly (1955). The activity of ascorbate peroxidase was analyzed by following the procedure of Asada (1987) and the activity of ascorbic acid was figured out by following the way of Mukherjee and Choudhuri (1983) with minor amendments. Fresh plant material (leaves) $(0.5 \mathrm{~g})$ was completely grounded in $5 \mathrm{~mL}$ of potassium phosphate buffer $(50 \mathrm{mM}) \mathrm{pH}$ (7.0) under ice-cold conditions and centrifuged at $15,000 \mathrm{rpm}$ and $4^{\circ} \mathrm{C}$ made the supernatant and stocked it at $-20^{\circ} \mathrm{C}$ for determination of antioxidants activities.

For determining CAT activity, a $2.5 \mathrm{~mL}$ potassium phosphate buffer was treated with $100 \mu \mathrm{l}$ of $\mathrm{H} 2 \mathrm{O} 2$ $(5.6 \mathrm{mM})$, then added $100 \mu \mathrm{l}$ of plant sample and CAT activity was checked at $240 \mathrm{~nm}$ via a spectrophotometer. Peroxidase reaction contains one $\mathrm{mL}$ of potassium buffer, $100 \mu \mathrm{l}$ of $(180 \mathrm{mM})$ guaiacol, $100 \mu \mathrm{l}$ of $(180 \mathrm{mM})$ $\mathrm{H}_{2} \mathrm{O}_{2}$ and then add $100 \mu \mathrm{l}$ of plant sample and checked the peroxidase activity at $470 \mathrm{~nm}$ by using a spectrophotometer. The ascorbate peroxidase (APX) reaction comprises $700 \mu \mathrm{l}$ of potassium phosphate buffer $(50 \mathrm{mM}), 100 \mu \mathrm{l}$ of ascorbic acid, $100 \mu \mathrm{l}$ of $(5.1 \mathrm{mM}) \mathrm{H}_{2} \mathrm{O}_{2}$ and then added $100 \mu \mathrm{l}$ of plant sample. Enzyme activity was checked at a wavelength of $290 \mathrm{~nm}$ via a spectrophotometer. The ASA activity was analyzed by treating the $2 \mathrm{~mL}$ of plant sample with DTC reagent $(0.5 \mathrm{~mL})$. Then the reaction mixture was left for $3 \mathrm{~h}$ at room temperature; after that, chilled $\mathrm{H}_{2} \mathrm{SO}_{4}$ was added slowly and left the mixture for $30 \mathrm{~min}$ at room temperature, then subjected to check the AsA contents at $520 \mathrm{~nm}$ via a spectrophotometer.

\section{Determination of Cd contents}

Accumulated Cd contents in plant tissue were analyzed by following the technique of $\mathrm{Hsu}$ and Kao (2003). A dried plant sample (0.5 g) was added in a conical flask and treated with (1:2) of concentrated (HCL and $\mathrm{HNO}_{3}$ ) and the reaction mixture was left for $3 \mathrm{~h}$ at room temperature. After that conical flask containing the reaction mixture was placed on a hot plate and heated until the brown fumes wiped out and a clear solution was obtained. This solution was then filtered into a small plastic bottle and diluted to $25 \mathrm{~mL}$ by adding the distal water. The final value of $\mathrm{Cd}$ content was determined by using atomic absorption spectrophotometry.

\section{Statistical analysis}

Data was subjected for statistical analysis using software STATISTIX 8.1 for ANOVA and the least significance difference (LSD) test will be used to check the significance of treatment means at a $5 \%$ probability level. 


\section{Results}

\section{Growth attributes}

Cadmium induced stress markedly reduced the related growth parameters (Table 2). Root and shoot length decreased significantly under different $\mathrm{Cd}$ concentrations however, the maximum reduction was observed at $15 \mathrm{mg} \mathrm{Cd} \mathrm{kg}^{-1}$ of soil. Shoot and root length were reduced by $34 \%$ and $40 \%$ respectively at higher $\mathrm{Cd}$ concentration $\left(15 \mathrm{mg} \mathrm{Cd} \mathrm{kg}{ }^{-1}\right.$ ) as related to control treatment. Similarly, exposure of plants to Cd also diminished the fresh and dry biomass of different plant tissues, nonetheless, the maximum reduction in root FW (56\%), shoot FW (51\%), root dry mass (62\%) and shoot dry mass (21\%) was recorded at $15 \mathrm{mg} \mathrm{Cd} \mathrm{kg}^{-1}$ as compared to control (Table 2). However, exogenous-applied SA prevented the plant growth from damaging effects of $\mathrm{Cd}$ stress and considerably amended all related growth parameters. Exogenous applied SA $\left(10^{-3} \mathrm{M}\right)$ improved the shoot and root length by (9\% and 39\%), shoot and root fresh biomass (43\%, 38\%), and dry biomass of shoot and root $(33 \%, 71 \%)$ respectively under $15 \mathrm{mg} \mathrm{Cd} \mathrm{kg}^{-1}$ level responding to its control (Table 2).

\section{Relative water contents and electrolyte leakage}

Relative water contents markedly decreased under Cd stress. Conversely, a significant increase in the electrolyte leakage was recorded under different concentrations of $\mathrm{Cd}$ (Figure 1). The highest value of electrolyte leakage was noted 69\%; while, water content was recorded as $46 \%$ under $15 \mathrm{mg} \mathrm{Cd} \mathrm{kg}^{-1}$ of soil. Exogenous application of SA improved the relative water contents by $23 \%$ and stables the ionic homeostasis by preventing membrane damage.

\section{Photosynthetic pigments}

The increasing concentration of $\mathrm{Cd}$ gradually decreased the chlorophyll contents in mung bean seedlings (Figure 2). The decrease in chlorophyll a and b was recorded as $24 \%$ and $27 \%$ respectively under a higher $\mathrm{Cd}$ level alone. On the other hand, exogenous SA improved the photosynthetic pigments under Cdinduced stress. Chlorophyll a and chlorophyll $b$ were increased in response to the exogenous application of SA even under a higher level of $\mathrm{Cd}$ stress. An escalation in chlorophyll a (5\%) and chlorophyll b (4\%) was recorded at $10^{-3} \mathrm{M}$ of exogenous-applied SA as compared to the water spray (Figure 2).

Table 2. Changes in growth attributes of mung bean (Vigna radiata L.) under different treatments of salicylic acid (SA) and cadmium (Cd)

\begin{tabular}{|c|c|c|c|c|c|c|c|c|}
\hline & & $\begin{array}{l}\text { Shoot length } \\
(\mathrm{cm})\end{array}$ & $\begin{array}{c}\text { Root length } \\
(\mathrm{cm})\end{array}$ & $\begin{array}{c}\text { Shoot fresh } \\
\text { weight }(\mathrm{g})\end{array}$ & $\begin{array}{l}\text { Root fresh } \\
\text { weight }(\mathrm{g})\end{array}$ & $\begin{array}{l}\text { Shoot dry } \\
\text { weight }(\mathrm{g})\end{array}$ & $\begin{array}{c}\text { Root dry } \\
\text { weight }(\mathrm{g})\end{array}$ & $\begin{array}{c}\text { Number of } \\
\text { leaves }\end{array}$ \\
\hline \multirow{3}{*}{$\mathrm{Cd}_{0}$} & $\mathrm{SA}_{0}$ & $25.17 c \pm 0.56$ & $5.30 c \pm 0.30$ & $4.68 c \pm 0.22$ & $1.02 c \pm 0.02$ & $0.62 \mathrm{~cd} \pm 0.03$ & $0.25 \mathrm{e} \pm 0.05$ & $10.50 \mathrm{~b} \pm 0.5$ \\
\hline & $S_{A_{1}}$ & $26.45 b \pm 0.64$ & $5.95 \mathrm{~b} \pm 0.05$ & $5.50 \mathrm{~b} \pm 0.30$ & $1.18 \mathrm{~b} \pm 0.02$ & $0.75 b \pm 0.02$ & $0.34 \mathrm{~b} \pm 0.02$ & $12.20 \mathrm{a} \pm 0.82$ \\
\hline & $\mathrm{SA}_{2}$ & $27.77 \mathrm{a} \pm 0.68$ & $8.92 \mathrm{a} \pm 0.37$ & $6.41 \mathrm{a} \pm 1.00$ & $1.33 \mathrm{a} \pm 0.04$ & $0.93 a \pm 0.04$ & $0.41 \mathrm{a} \pm 0.007$ & $13.0 \mathrm{a} \pm 0.70$ \\
\hline \multirow{3}{*}{$\mathrm{Cd}_{1}$} & $\mathrm{SA}_{0}$ & $22.00 \mathrm{e} \pm 0.55$ & $4.60 \mathrm{e} \pm 0.1$ & $4.03 \mathrm{~d} \pm 0.22$ & $0.74 \mathrm{f} \pm 0.01$ & $0.65 c \pm 0.03$ & $0.25 \mathrm{e} \pm 0.005$ & $8.50 \mathrm{def} \pm 0.86$ \\
\hline & $\mathrm{SA}_{1}$ & $23.35 \mathrm{~d} \pm 0.35$ & $4.87 \mathrm{fg} \pm 0.40$ & $4.59 c \pm 0.30$ & $0.88 \mathrm{~d} \pm 0.02$ & $0.74 \mathrm{~b} \pm 0.02$ & $0.30 \mathrm{~cd} \pm 0.08$ & $9.50 \mathrm{bcd} \pm 0.5$ \\
\hline & $\mathrm{SA}_{2}$ & $25.17 \mathrm{c} \pm 0.85$ & $5.77 \mathrm{~b} \pm 0.22$ & $4.67 c \pm 0.11$ & $1.00 c \pm 0.01$ & $0.77 \mathrm{~b} \pm 0.04$ & $0.38 \mathrm{a} \pm 0.01$ & $10.25 b c \pm 0.43$ \\
\hline \multirow{3}{*}{$\mathrm{Cd}_{2}$} & $\mathrm{SA}_{0}$ & $18.25 \mathrm{fg} \pm 04$ & $3.87 \mathrm{~g} \pm 0.08$ & $3.25 \mathrm{e} \pm 0.08$ & $0.54 \mathrm{~h} \pm 0.01$ & $0.57 \mathrm{de} \pm 0.03$ & $0.26 \mathrm{e} \pm 0.01$ & $8.00 \mathrm{fg} \pm 0.40$ \\
\hline & $\mathrm{SA}_{1}$ & $21.62 \mathrm{e} \pm 0.73$ & $4.20 \mathrm{f} \pm 0.21$ & $3.58 \mathrm{de} \pm 0.23$ & $0.65 \mathrm{fg} \pm 0.02$ & $0.63 c \pm 0.02$ & $0.27 \mathrm{de} \pm 0.01$ & $8.25 \mathrm{efg} \pm 0.24$ \\
\hline & $\mathrm{SA}_{2}$ & $23.02 \mathrm{~d} \pm 0.35$ & $4.97 \mathrm{~cd} \pm 0.10$ & $4.02 \mathrm{~d} \pm 0.08$ & $0.82 \mathrm{~d} \pm 0.03$ & $0.74 \mathrm{~b} \pm 0.03$ & $0.32 b c \pm 0.01$ & $9.25 \mathrm{cde} \pm 0.47$ \\
\hline \multirow{3}{*}{$\mathrm{Cd}_{3}$} & $\mathrm{SA}_{0}$ & $15.50 \mathrm{~h} \pm 0.55$ & $3.15 \mathrm{~h} \pm 0.11$ & $2.30 \mathrm{f} \pm 0.47$ & $0.45 \mathrm{i} \pm 0.01$ & $0.49 \mathrm{f} \pm 0.03$ & $0.15 \mathrm{~g} \pm 0.01$ & $6.00 \mathrm{~h} \pm 0.40$ \\
\hline & $\mathrm{SA}_{1}$ & $17.67 \mathrm{~g} \pm 0.72$ & $3.77 \mathrm{~g} \pm 0.08$ & $3.17 \mathrm{e} \pm 0.65$ & $0.55 \mathrm{~h} \pm 0.01$ & $0.56 \mathrm{e} \pm 0.03$ & $0.21 \mathrm{f} \pm 0.01$ & $7.25 \mathrm{~g} \pm 0.47$ \\
\hline & $\mathrm{SA}_{2}$ & $18.62 \mathrm{f} \pm 0.41$ & $4.72 \mathrm{de} \pm 0.08$ & $3.28 \mathrm{e} \pm 0.21$ & $0.62 \mathrm{~g} \pm 0.01$ & $0.65 c \pm 0.02$ & $0.26 \mathrm{e} \pm 0.01$ & $8.00 \mathrm{fg} \pm 0.40$ \\
\hline \multicolumn{2}{|c|}{ LSD at $5 \%$} & $0.713^{* *}$ & $0.357^{* *}$ & $0.480^{* *}$ & $0.045^{*}$ & $0.053^{* *}$ & $0.031^{* *}$ & $1.14^{\mathrm{N} . \mathrm{S}}$ \\
\hline
\end{tabular}

Different letters within each column indicate significant difference at $5 \%$ probability level. ${ }^{* *}=$ highly significant; ${ }^{*}$, significant; $\mathrm{NS}=$ non-significant. 

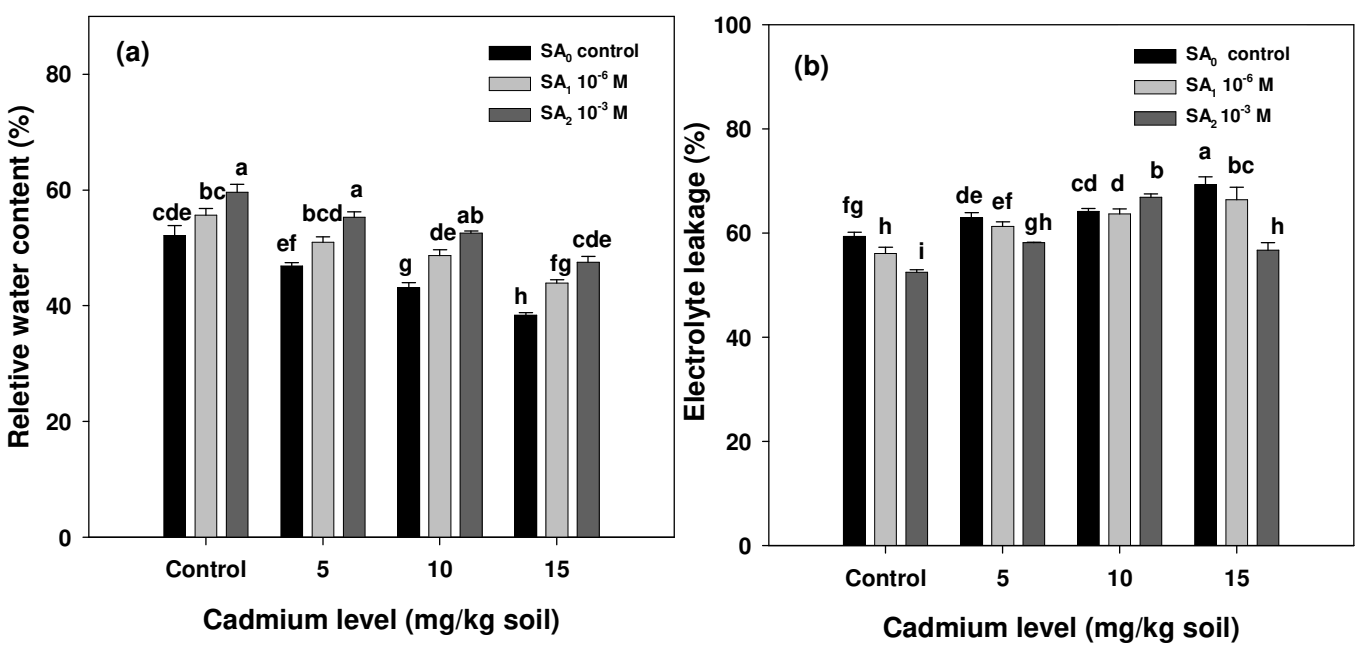

Figure 1. Effects of salicylic acid (SA) and cadmium (Cd) treatments on (a) relative water content, and (b) electrolyte leakage in the leaves of mung bean

Error bars represent the standard error at a $5 \%$ probability level under the LSD test.
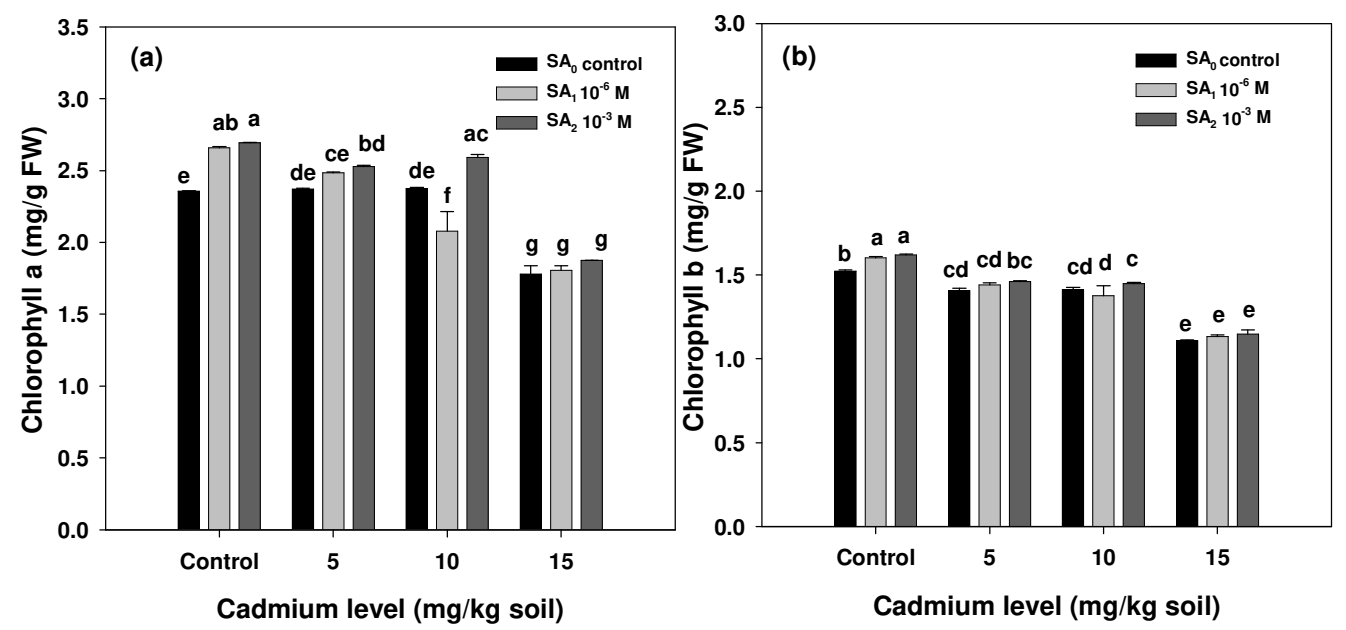

Figure 2. Effects salicylic acid (SA) and cadmium (Cd) treatments on photosynthetic pigments (a) chlorophyll a, and (b) chlorophyll $b$ in the leaves of mung bean

Error bars represent the value of standard error at a $5 \%$ probability level under the LSD test.

\section{Total soluble protein and free amino acids}

Cadmium stress exhibited a substantial reduction in the total soluble proteins and free amino acids (Figure 3). A sharp reduction in TSP 55\% and free amino acids $49 \%$ was found under $15 \mathrm{mg} \mathrm{Cd} \mathrm{kg}^{-1}$ of soil without exogenous-applied SA. However, exogenous application of SA boosted the total soluble protein under control conditions even a gradual increase was observed at the different concentrations of $\mathrm{Cd}$. Exogenous application of SA $10^{-3} \mathrm{M}$ upturn the total soluble protein by $39 \%$ under $15 \mathrm{mg} \mathrm{Cd} \mathrm{kg}^{-1}$ of soil as compared to water spray but it had no significant effects on total free amino acids (Figure 3 ).

\section{Lipid peroxidation}

Membrane damage is analyzed in terms of MDA and $\mathrm{H}_{2} \mathrm{O}_{2}$ and they are used as a key to membrane damage in the biological system. The $\mathrm{H}_{2} \mathrm{O}_{2}$ and MDA contents were elevated under increasing concentrations of Cd (Figure 3). The higher concentration of $\mathrm{H}_{2} \mathrm{O}_{2}(14.25 \mu \mathrm{mol})$ and $\mathrm{MDA}(6.90 \mathrm{nmol})$ were observed under 
$15 \mathrm{mg} \mathrm{Cd} \mathrm{kg}$ of soil without foliar-applied SA. A minimum concentration of $\mathrm{H}_{2} \mathrm{O}_{2}(9.49 \mu \mathrm{mol})$ and MDA $(2.59 \mathrm{nmol})$ was noticed under control conditions. Moreover, foliar application of SA at a concentration of 10${ }^{3} \mathrm{M}$ significantly reduced the MDA and $\mathrm{H}_{2} \mathrm{O}_{2}$ contents by $28 \%$ and $23 \%$ respectively at the $15 \mathrm{mg} \mathrm{Cd} \mathrm{kg}$ of soil as compared to water spray (Figure 3 ).
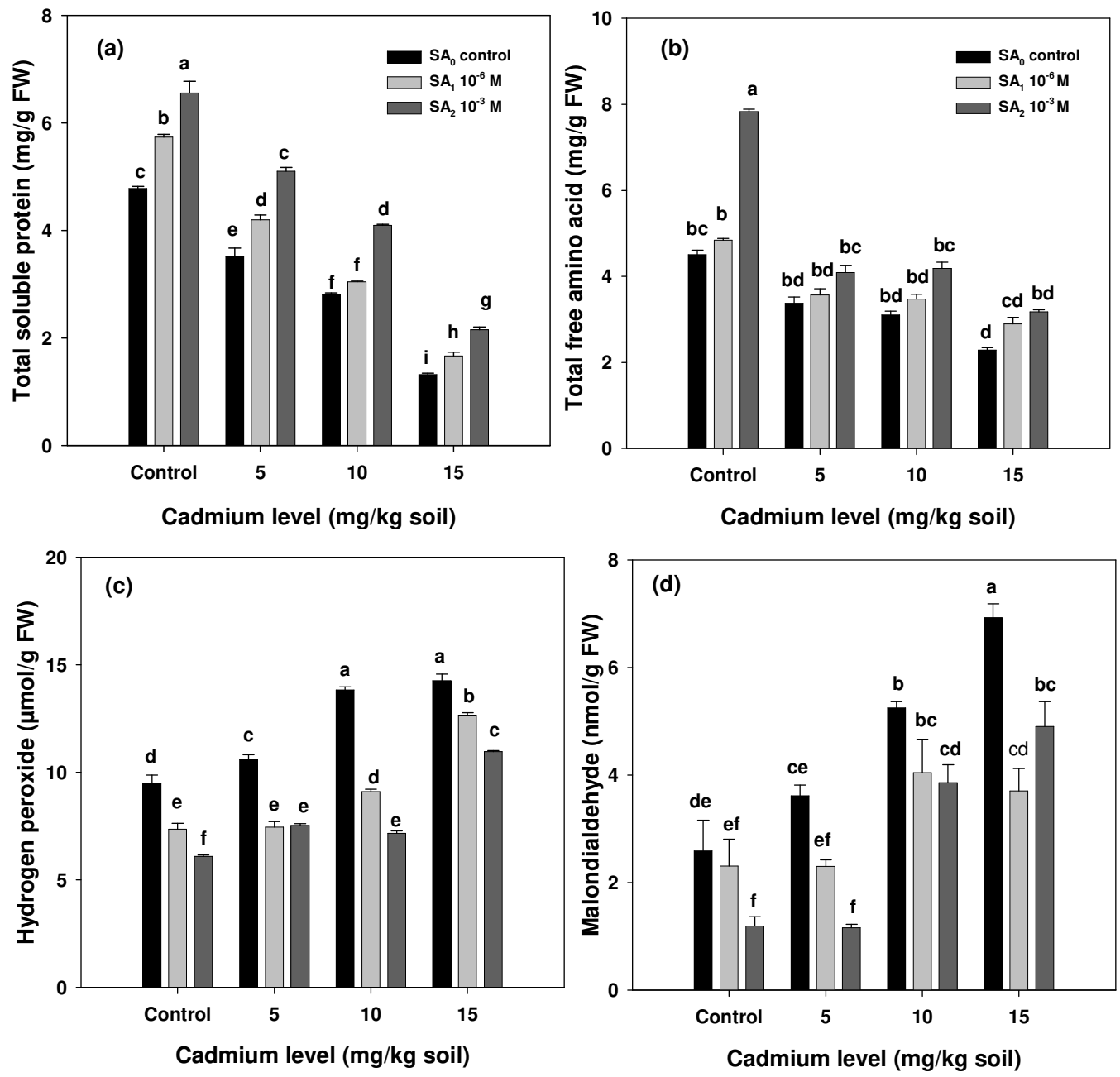

Figure 3. Effects of salicylic acid (SA) and cadmium (Cd) treatments on contents of (a) total soluble protein, (b) total free amino acid, (c) hydrogen peroxide, and (d) malondialdehyde of mung bean Error bars represent the standard error at a 5\% probability level under the LSD test.

\section{Antioxidants}

The results regarding the enzymatic antioxidant activities including CAT, POD, APX and AsA have been shown in Figure 4. Results revealed that $\mathrm{Cd}$-induced stress considerably increased the antioxidant enzyme activities related to the control treatment. However, folia- applied SA induced the additive effects in antioxidants under stress and control conditions but it has no significant effects on CAT activity. The activities of POD, APX and AsA were improved by $48 \%, 22 \%$ and $18 \%$, respectively at $15 \mathrm{mg} \mathrm{Cd} \mathrm{kg}^{-1}$ of soil in counter to the $10^{-3} \mathrm{M}$ of foliar-applied SA as compared to control treatment (water spray). 

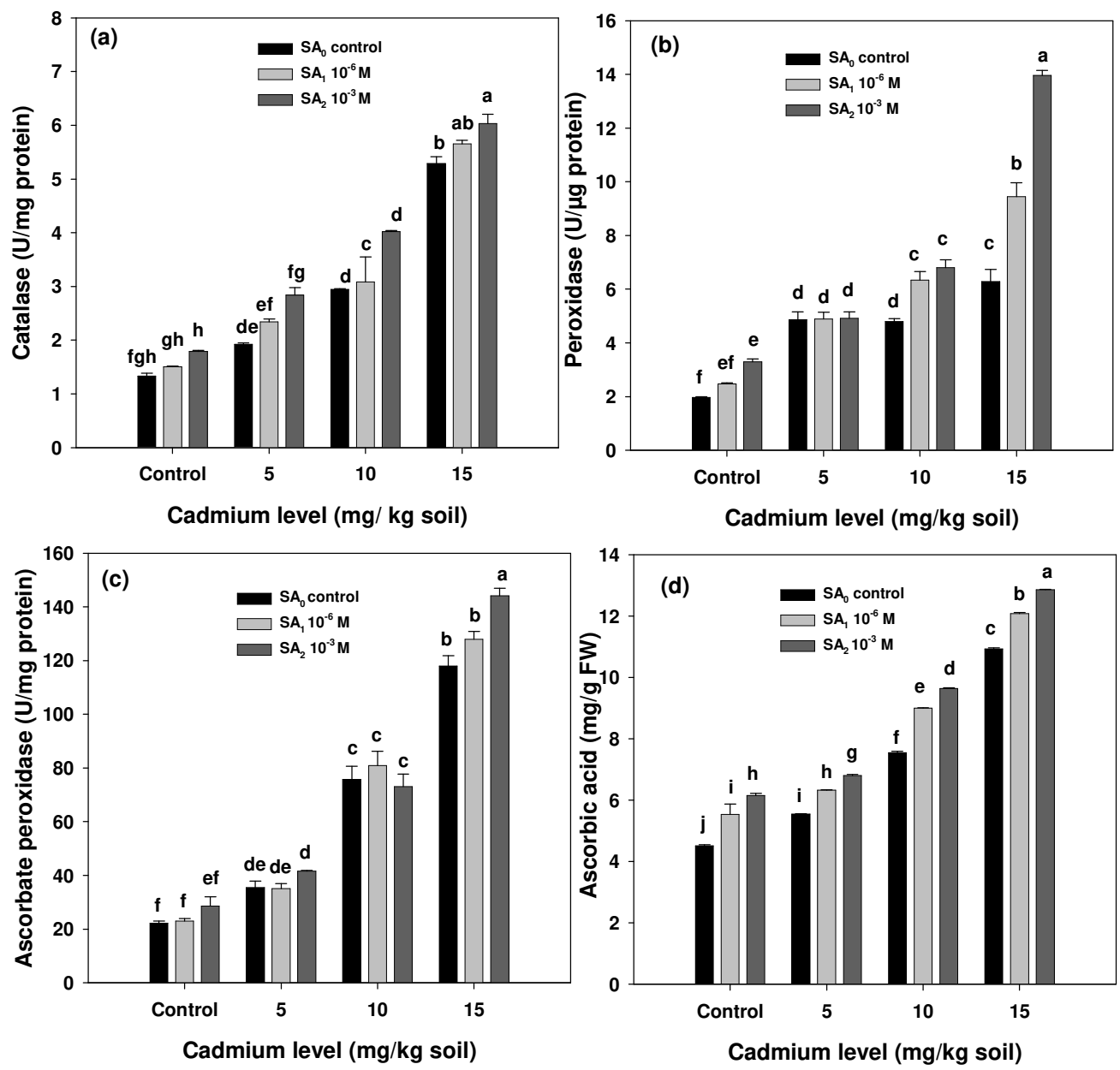

Figure 4. Effects salicylic acid (SA) and cadmium (Cd) treatments on antioxidant enzyme activities (a) catalase, (b) peroxidase, (c) ascorbate peroxidase and (d) ascorbic acid of mung bean Error bars represent the standard error at a 5\% probability level under the LSD test.

\section{Cadmium contents in shoot and root}

As expected, Cd uptake was observed higher in roots as compared to shoot of mung bean seedlings (Figure 5). Without exogenous applied SA, Cd uptake in shoots and roots was recorded as $36 \%$ and $50 \%$ respectively at maximum $\mathrm{Cd}$ level $\left(15 \mathrm{mg} \mathrm{Cd} \mathrm{kg}^{-1}\right.$ of soil) as relates to the control treatment. Although both levels of foliar-applied SA significantly reduced the Cd uptake under all stress levels, the application of SA at $10^{-3} \mathrm{M}$ level considerably suppressed the $\mathrm{Cd}$ uptake in shoot and root under $15 \mathrm{mg} \mathrm{Cd} \mathrm{kg}$ of soil as compared to respective control. 

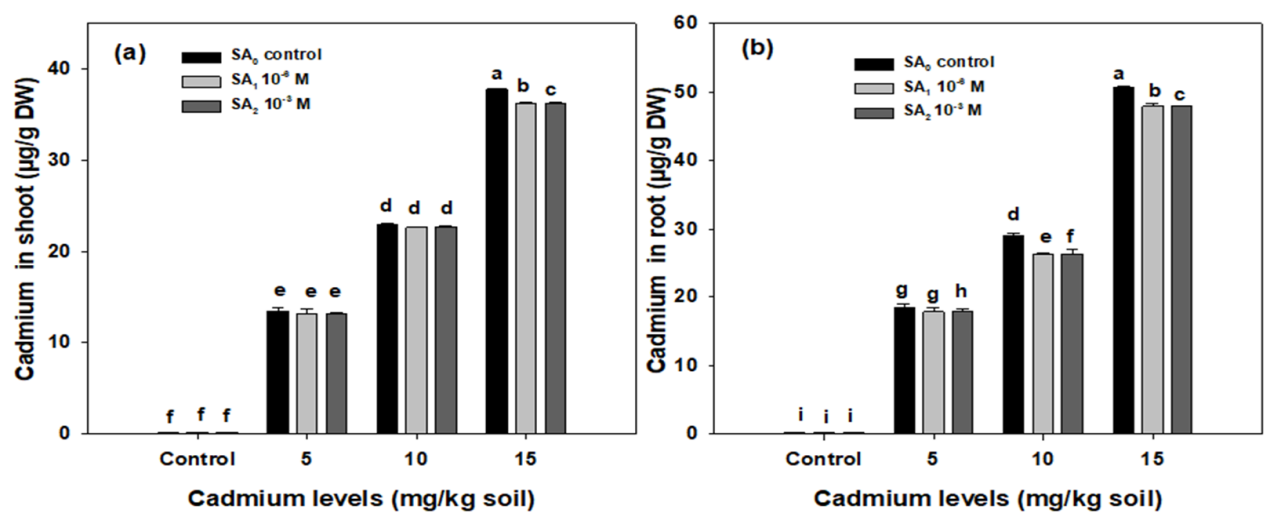

Figure 5. Effects of salicylic acid (SA) and cadmium (Cd) treatments on Cd uptake (a) Cd content in shoot (b), and Cd content in root of mung bean

Error bars represent the standard error at a 5\% probability level under the LSD test.

\section{Discussion}

Cadmium induced stress significantly reduced the growth by influencing the dry and fresh biomass of mung bean plants. In the current study, the substantial reduction was recorded at $15 \mathrm{mg} \mathrm{Cd} \mathrm{kg}^{-1}$ of soil in all related growth parameters (Table 2). Previous studies showed that suppression in related growth traits might be due fact that $\mathrm{Cd}$ toxicity inhibits the cell elongation and expansion before the cell division starts. Root growth is highly impaired on contact to the Cd in soil (Shakirova et al., 2007), which ultimately affects the root growth and lessen the root hairs. In addition, it is observed that $\mathrm{Cd}$ stress inhibits the water uptake and disturbed cellular homeostasis. This study showed that treatment of SA significantly promoted plant growth against $\mathrm{Cd}$ toxicity (Table 2). Plant growth also significantly improved in Cd-free plants in comeback with the foliar application of SA. Outcomes of this study can be related to previous studies where researchers identified that $\mathrm{SA}$ ameliorated the harmful effects of $\mathrm{Cd}$ and showed positive effects on mung bean growth which may be accompanied by maximum induction of indole acetic acid (IAA) activity that promote the rapid cell division in the apical meristematic region (Shakirova et al., 2007). In this study SA proved as an imminent molecule that enhances the plant growth under the high level of Cd-induced stress.

Our results demonstrated the degradation of photosynthetic pigments chlorophyll a and b Cd's increasing concentration (Figure 2). One of the visible symptoms of pigment loss is the chlorosis of plant leaves that might be due to the reticence of the chlorophyll biosynthesis (Pietrini et al., 2003). Induction of Cd stress displaces the ultra-structure of chloroplast mainly grana length (Souza et al., 2005). The main component of chlorophyll $\mathrm{Mg}^{2+}$ also disturbs under Cd stress and it ultimately affects the activity of PS II that becomes the reason for changing the redox balance across the $\mathrm{Z}$ scheme. Earlier findings have exposed that deterioration and depletion of photosynthetic pigments in contradiction of HM stress that could direct the conflict in the electron transport chain of PS I and PS II, also ensuing the assembly of ROS.

Exogenous application of SA significantly ameliorates the Cd-induced stress for the photosynthetic pigments. This is an expression that SA alleviates the adverse effect of MDA and ROS affected by Cr stress (Gill et al., 2016). Proteins are multipurpose molecules that perform various functions in living cells, but their activity is degraded under heavy metal stress (Goldberg 2003). In the current study, it is clear that the total soluble proteins and free amino acids declined under increasing Cd levels and were elevated by the SA treatment (Figure 3). This reduction may be due to inadequate functioning of the plasma membrane, metal ions also inhibit the binding of cysteine-rich, induce changes at nucleotide-binding site leading to affect the chain of amino acids that ultimately inhibit protein synthesis. There are diverse findings of the functioning of proteins 
in cells under biotic stress, similar findings were observed in Vigna radiata under salinity and SA treatment (Akhtar et al., 2013).

Increasing concentration of $\mathrm{Cd}$ significantly enhance the cellular damage as shown in (Figure 1). An increasing level of electrolyte leakage may be possible due to changes in structure of plasma membrane, ionic transport across membrane also the changes in cellular homeostasis. Exposure of the mung bean plants to $\mathrm{Cd}$ stress results in an elevated level of ROS that leads towards membrane damage and the production of free radicals (Anjum et al., 2011). In the current study, we examined that exposure to the $\mathrm{Cd}$ stress brings the oxidative disruption by the production of ROS estimated by the analysis of MDA and $\mathrm{H}_{2} \mathrm{O}_{2}$ contents in leaves (Figure 3). By-products of $\mathrm{H}_{2} \mathrm{O}_{2}$, free radicals and hydroxyl ions alter the regular circuit of the electron transport chain, ultimately disturb the redox potential at the final electron acceptor of the mitochondrial membrane (Laspina et al., 2005; Guo et al., 2013). Further, foliar-applied SA competed for the MDA and $\mathrm{H}_{2} \mathrm{O}_{2}$ contents under $\mathrm{Cd}$ stress that was proposed to be a membrane stabilizer because of its aptitude to act as an antioxidant scavenger against ROS (Gill et al., 2016).

Plants have a natural scavenging system against abiotic stresses called as the enzymatic and nonenzymatic antioxidants that fight against the ROS (Nagamiya et al., 2007). Exogenous applied SA significantly enhanced the defense system of mung bean plants by enhancing antioxidants activity (CAT, POD, APX and AsA) under increasing Cd levels (Figure 4). Antagonistic results of SA were observed in this study as MDA and $\mathrm{H}_{2} \mathrm{O}_{2}$ contents decreased by the application of SA. However, exogenous SA increased the activities of antioxidants under $\mathrm{Cd}$ stress, so it is proved as an important defensive molecule. Our findings delineated that antioxidant enzyme activities are directly or indirectly regulated through SA application; thus, this molecule acts as a stabilizer against $\mathrm{Cd}$ stress. The possible explanation about $\mathrm{SA}$ against $\mathrm{ROS}$ may enhance the regulation of NADPH loops in a specific cellular compartment to produce positive signals against abiotic stresses (Mittler et al., 2004). As expected that $\mathrm{Cd}$ contents were more in roots as compared to shoot (Figure 5) which provides clear evidence the roots are the partisan site of Cd accumulation (Bezrukova et al., 2011). However, foliarapplied SA helped to reduce the Cd uptake in mung bean plants (Figure 5) SA act as a barrier for Cd uptake in the root zone that could be facilitated by the upturn of citrate efflux in roots of the SA treated plants (Yang et al., 2003).

\section{Conclusions}

This study revealed that $\mathrm{Cd}$ stress significantly decreased the growth of mung bean seedlings mainly by altering physiological and biochemical processes. Meanwhile, SA considerably improved the plant growth and antioxidant defense system against $\mathrm{Cd}$ suggesting that $\mathrm{SA}$ detoxifies the $\mathrm{Cd}$-induced stress, thus it is involved in the modulation of the metabolic process. Improvement in morphological, physiological and biochemical processes of mung bean against $\mathrm{Cd}$ stress was approached by foliar application of $10^{-3} \mathrm{M}$ of SA. Furthermore, comprehensive experimentation relating latest molecular practices are required to fix the defined mechanism underlying SA-induced Cd stress tolerance.

\section{Authors' Contributions}

Conceptualization: IK, MC, MS, RJ, FM, WI and MH; Formal analysis: FH, EA, MS, BA, RR, OU and WI; Investigation: IK and WI; Methodology: IK, MC, MS, RJOU, FH, FM, WI and MH; Writing - original draft: IK, WI, FM, MS and MH; Writing - review and editing: MS, OU, RR, RJ, BA, FH, EA and MC; All authors read and approved the final manuscript. 


\section{Acknowledgements}

The authors are thankful to the Taif University Researchers Supporting Project number (TURSP2020/143), Taif University, Taif, Saudi Arabia for providing the financial support and research facilities.

\section{Conflict of Interests}

The authors declare that there are no conflicts of interest related to this article.

\section{References}

Abbas MS, Akmal M, Ullah S, Hassan MU, Farooq S (2017). Effectiveness of zinc and gypsum application against cadmium toxicity and accumulation in wheat (Triticum aestivum L.). Communications in Soil Science and Plant Analysis 48:1659-1668. https://doi.org/10.1080/00103624.2017.1373798

Acar O, Türkan I, Özdemir F (2001). Superoxide dismutase and peroxidase activities in drought sensitive and resistant barley (Hordeum vulgare L.) varieties. Acta Physiologiae Plantarum 23:351-356. https://link.springer.com/article/10.1007/s11738-001-0043-8

Akhtar J, Ahmad R, Ashraf MY, Tanveer A, Waraich EA, Oraby H (2013). Influence of exogenous application of salicylic acid on salt-stressed mungbean (Vigna radiata): growth and nitrogen metabolism. Pakistan Journal of Botany 45:119-125. https://www.pakbs.org/pjbot/PDFs/45(1)/15.pdf

Aamir M, Hassan MU, Li Z, A Ali, Su Q, Liu L, ... Guaqin H (2018). Foliar application of glycinebetaine alleviates the cadmium toxicity in spinach through reducing $\mathrm{Cd}$ uptake and improving the activity of anti-oxidant system. Applied Ecology and Environmental Research 16(6):7575-7583. http://dx.doi.org/10.15666/aeer/1606_75757583

Al-Ashkar I, Alderfasi A, Ben Romdhane W, Seleiman MF, El-Said RA, Al-Doss A (2020). Morphological and genetic diversity within salt tolerance detection in eighteen wheat genotypes. Plants 9:287. https://doi.org/10.3390/plants9030287

Anjum NA, Umar S, Iqbal M, Khan NA (2011). Cadmium causes oxidative stress in mung bean by affecting the antioxidant enzyme system and ascorbate-glutathione cycle metabolism. Russian Journal of Plant Physiology 58:92-99. https://link.springer.com/article/10.1134/S1021443710061019

Arnon DI (1949). Copper enzymes in isolated chloroplasts. Polyphenoloxidase in Beta vulgaris. Plant Physiology 24:114. https://doi.org/10.1104/pp.24.1.1

Asada K (1987). Production and scavenging of active oxygen in photosynthesis. Photoinhibition 227-287.

Barceló J, Poschenrieder C (1990). Plant water relations as affected by heavy metal stress: a review. Journal of Plant Nutrition 13:1-37. https://doi.org/10.1080/01904169009364057

Bezrukova MV, Fatkhutdinova RA, Lubyanova AR, Murzabaev AR, Fedyaev VV, Shakirova FM (2011). Lectin involvement in the development of wheat tolerance to cadmium toxicity. Russian Journal of Plant Physiology 58:1048-1056. https://link.springer.com/article/10.1134/S1021443711060021

Bradford MM (1976). A rapid and sensitive method for the quantitation of microgram quantities of protein utilizing the principle of protein-dye binding. Annals of Biochemistry 72:248-254. https://doi.org/10.1006/abio.1976.9999

Cakmak I, Horst WJ (1991). Effect of aluminium on lipid peroxidation, superoxide dismutase, catalase, and peroxidase activities in root tips of soybean (Glycine max). Physiologia Plantarum 83:463-468. https://doi.org/10.1111/j.1399-3054.1991.tb00121.x

Ekmekçi Y, Tanyolac D, Ayhan B (2008). Effects of cadmium on antioxidant enzyme and photosynthetic activities in leaves of two maize cultivars. Journal of Plant Physiology 165:6000611. https://doi.org/10.1016/j.jplph.2007.01.017

Elahi NN, Mustafa S, Mirza JI (2004). Growth and nodulation of mungbean (Vigna radiata (L.) Wilczek) as affected by sodium chloride. Journal of Research and Science of Bahauddin Zakaria Univ Multan, Pakistan 15:139-143. https://www.bzu.edu.pk/jrscience/vol15no2/3.pdf 
Gill RA, Zhang N, Ali B, Farooq MA, Xu J, Gill MB, ... Zhou W (2016). Role of exogenous salicylic acid in regulating physio-morphic and molecular changes under chromium toxicity in black-and yellow-seeded Brassica napus L. Environmental Science and Pollution Research 23:20483-20496. https://doi.org/10.1007/s11356-016-7167-2

Goldberg AL (2003). Protein degradation and protection against misfolded or damaged proteins. Nature 426:895. https://doi.org/10.1038/nature02263

Guo Q, Meng L, Mao PC, Jia YQ, Shi YJ (2013). Role of exogenous salicylic acid in alleviating cadmium-induced toxicity in Kentucky bluegrass. Biochemical Systematices and Ecology 50:269-276. https://doi.org/10.1016/j.bse.2013.05.002

Hassan MU, Chattha MU, Khan I, Chattha MB, Aamer M, Nawaz M, ... Khan TA (2019). Nickel toxicity in plants: reasons, toxic effects, tolerance mechanisms, and remediation possibilities-a review. Environmental Sciences and Pollution Research 26:12673-12688. https://doi.org/10.1007/s11356-019-04892-X

Hassan MU, Aamer M, Chattha MU, Haiying T, Shahzad B, Barbanti L, ... Guoqin H (2020). The critical role of zinc in plants facing the drought stress. Agriculture 10(9):396. https://doi.org/10.3390/agriculture10090396

Hassan MU, Muhammad A, Chattha MU, Haiying T, Khan I, Seleiman MF, ... Afzal A (2021). Sugarcane distillery spent wash (dsw) as a bio-nutrient supplement: a win-win option for sustainable crop production. Agronomy 11:183. https://doi.org/10.3390/agronomy11010183

Hafez EH, Seleiman MF (2017). Response of barley quality traits, yield and antioxidant enzymes to water-stress and chemical inducers. International Journal of Plant Production 11:477-490.

Hayat Q, Hayat S, Irfan M, Ahmad A (2010). Effect of exogenous salicylic acid under changing environment: a review. Environmental and Experimental Botany 68:14-25. https://doi.org/10.1016/j.envexpbot.2009.08.005

Hsu YT, Kao CH (2003). Role of abscisic acid in cadmium tolerance of rice (Oryza sativa L.) seedlings. Plant Cell and Environment 26:867-874. https://doi.org/10.1046/j.1365-3040.2003.01018.x

Klessig DF (2017). How does the multifaceted plant hormone salicylic acid combat disease in plants and are similar mechanisms utilized in humans? BMC Biology 15:1-23. https://doi.org/10.1186/s12915-017-0364-8

Krantev A, Yordanova R, Janda T, Szalai G, Popova L (2008). Treatment with salicylic acid decreases the effect of cadmium on photosynthesis in maize plants. Journal of Plant Physiology 165:920-931. https://doi.org/10.1016/j.jplph.2006.11.014

Laspina N V, Groppa MD, Tomaro ML, Benavides MP (2005). Nitric oxide protects sunflower leaves against Cd-induced oxidative stress. Plant Science 169:323-330. https://doi.org/10.1016/j.plantsci.2005.02.007

Liu J, Qian M, Cai G, Yang J, Zhu Q (2007). Uptake and translocation of Cd in different rice cultivars and the relation with $\mathrm{Cd}$ accumulation in rice grain. Journal of Hazardous Materials 143:443-447. https://doi.org/10.1016/j.jhazmat.2006.09.057

Mittler R, Vanderauwera S, Gollery M, Van Breusegem F (2004). Reactive oxygen gene network of plants. Trends in Plant Science 9:490-498. https://doi.org/10.1016/j.tplants.2004.08.009

Moore S, Stein WH (1954). A modified ninhydrin reagent for the photometric determination of amino acids and related compounds. Journal of biology and Chemistry 211:907-913. https://doi.org/10.1016/S0021-9258(18)71178-2

Mukherjee SP, Choudhuri MA (1983). Implications of water stress-induced changes in the levels of endogenous ascorbic acid and hydrogen peroxide in Vigna seedlings. Physiology of Plants 58:166-170. https://doi.org/10.1111/j.13993054.1983.tb04162.x

Nagamiya K, Motohashi T, Nakao K, Prodhan SH, Hattori E, Hirose S, ... Takabe T (2007). Enhancement of salt tolerance in transgenic rice expressing an Escherichia coli catalase gene. Plant Biotechnology Reports 1:49-55. https://link.springer.com/article/10.1007/s11816-007-0007-6

Noriega G, Caggiano E, Lecube ML, Santa Cruz D, Batlle A, Tomaro M, Balestrasse KB (2012). The role of salicylic acid in the prevention of oxidative stress elicited by cadmium in soybean plants. Biometals 25:1155-1165. https://link.springer.com/article/10.1007/s10534-012-9577-z

Oweis T, Pala M, Ryan J (1999). Management alternatives for improved durum wheat production under supplemental irrigation in Syria. European Journal of Agronomy 11:255-266. https://doi.org/10.1016/S1161-0301(99)000362

Pietrini F, Iannelli MA, Pasqualini S, Massacci A (2003). Interaction of cadmium with glutathione and photosynthesis in developing leaves and chloroplasts of Phragmites australis (Cav.) Trin. ex Steudel. Plant Physiology 133:829-837. https://doi.org/10.1104/pp.103.026518 
Rasheed A, Fahad S, Aamer M, Hassan MU, Tahir MM, Wu ZM (2020). Role of genetic factors in regulating cadmium uptake, transport and accumulation mechanisms and quantitative trait loci mapping in rice. Applied Ecology and Environmental Research 18(3):4005-4023. http://dx.doi.org/10.15666/aeer/1803_40054023

Salem HM, Abdel-Salam A, Abdel-Salam MA, Seleiman MF (2018). Phytoremediation of metal and metalloids from contaminated soil. In: Plants Under Metal and Metalloid Stress. Springer Nature Singapore Pte Ltd.: Singapore, pp 249-262.

Saleem MH, Ali S, Seleiman MF, Rizwan M, Rehman M, Aisha AN, ... Mubushar M (2019). Assessing the Correlations between different traits in copper-sensitive and copper-resistant varieties of jute (Corchorus capsularis L.). Plants 8:545. https://doi.org/10.3390/plants8120545

Seleiman MF, Ali S, Refay Y, Rizwan M, Alhammad BA, El-Hendawy SE (2020a). Chromium resistant microbes and melatonin reduced $\mathrm{Cr}$ uptake and toxicity, improved physio-biochemical traits and yield of wheat in contaminated soil. Chemosphere 250:126239. https://doi.org/10.1016/j.chemosphere.2020.126239

Seleiman MF, Almutairi KF, Alotaibi M, Shami A, Alhammad BA, Battaglia ML (2021a). Nano-fertilization as an emerging fertilization technique: why can modern agriculture benefit from its use? Plants 10:2. https://doi.org/10.3390/plants10010002

Seleiman MF, Alotaibi MA, Alhammad BA, Alharbi BM, Refay Y, Badawy SA (2020c). Effects of ZnO nanoparticles and biochar of rice straw and cow manure on characteristics of contaminated soil and sunflower productivity, oil quality, and heavy metals uptake. Agronomy 10:790. https://doi.org/10.3390/agronomy10060790

Seleiman MF, Al-Suhaibani N, Ali N, Akmal M, Alotaibi M, Refay Y, ... Battaglia ML (2021b) Drought stress impacts on plants and different approaches to alleviate its adverse effects. Plants 10:259. https://doi.org/10.3390/plants10020259.

Seleiman MF, Santanen A, Jaakkola S, Ekholm P, Hartikainen H, Stoddard FL, Mäkelä PS (2013). Biomass yield and quality of bioenergy crops grown with synthetic and organic fertilizers. Biomass Bioenergy 59:477-485.

Seleiman MF, Santanen A, Mäkelä PS (2020b). Recycling sludge on cropland as fertilizer-advantages and risks. Resource Conservation and Recycling 155:104647. https://doi.org/10.1016/j.resconrec.2019.104647

Seleiman MF, Santanen A, Stoddard FL, Mäkelä P (2012). Feedstock quality and growth of bioenergy crops fertilized with sewage sludge. Chemosphere 89:1211-1217. https://doi.org/10.1016/j.chemosphere.2012.07.031

Seleiman MF, Selim S, Jaakkola S, Mäkelä PS (2017) Chemical composition and in vitro digestibility of whole-crop maize fertilized with synthetic fertilizer or digestate and harvested at two maturity stages in Boreal growing conditions. Agricultural and Food Science 26:47-55.

Shakirova FM (2007). Role of hormonal system in the manifestation of growth promoting and antistress action of salicylic acid. In Salicylic acid: a plant hormone. Springer, Dordrecht, pp 69-89.

Shao X, Yang H, Ran K, Jiang Q, Sun X (2010). Effects of salicylic acid on plasma membrane ATPase and free radical of grape root under cadmium stress. Scientia Agricultura Sinica 43:1441-1447. https://doi.org/10.3864/j.issn.05781752.2010.07.015

Shi Q, Zhu Z (2008). Effects of exogenous salicylic acid on manganese toxicity, element contents and antioxidative system in cucumber. Environment and Experimental Botany 317-326. https://doi.org/10.1016/j.envexpbot.2007.11.003

Šimonová E, Henselová M, Masarovičová E, Kohanová J (2007). Comparison of tolerance of Brassica juncea and Vigna radiata to cadmium. Biology of Plants 51:488-492. https://link.springer.com/article/10.1007/s10535-007-0103$z$

Singh PK, Gautam S (2013). Role of salicylic acid on physiological and biochemical mechanism of salinity stress tolerance in plants. Acta Physiologia Plantrum 35:2345-2353. https://link.springer.com/article/10.1007/s11738-0131279-9

Sofy MR, Seleiman MF, Alhammad BA, Alharbi BM, Mohamed HI, (2020). Minimizing adverse effects of pb on maize plants by combined treatment with jasmonic, salicylic acids and proline. Agronomy 10:699. https://doi.org/10.3390/agronomy10050699

Souza JF, Dolder H, Cortelazzo AL (2005). Effect of excess cadmium and zinc ions on roots and shoots of maize seedlings. Journal of Plant Nutrition 28:1923-1931. https://doi.org/10.1080/01904160500310435

Türkan I, Bor M, Özdemir F, Koca H (2005). Differential responses of lipid peroxidation and antioxidants in the leaves of drought-tolerant $P$. acutifolius Gray and drought-sensitive $P$. vulgaris $\mathrm{L}$. subjected to polyethylene glycol mediated water stress. Plant Science 168:223-231. https://doi.org/10.1016/j.plantsci.2004.07.032 
Turner NC (1981). Techniques and experimental approaches for the measurement of plant water status. Plant Soil 58:339-366. https://link.springer.com/article/10.1007/BF02180062

Uslu OS, Babur E, Alma MH, Solaiman ZM (2020). Walnut shell biochar increases seed germination and early growth of seedlings of fodder crops. Agriculture 10:427. https://doi.org/10.3390/agriculture10100427

Vassilev A, Perez-Sanz A, Semane B, Carleer R, Vangronsveld J (2005). Cadmium accumulation and tolerance of two Salix genotypes hydroponically grown in presence of cadmium. Journal of Plant Nutrition 28:2159-2177.

Velikova V, Yordanov I, Edreva A (2000). Oxidative stress and some antioxidant systems in acid rain-treated bean plants: protective role of exogenous polyamines. Plant Science 151:59-66. https://doi.org/10.1016/S01689452(99)00197-1

Wahid A, Ghani A, Javed F (2008). Effect of cadmium on photosynthesis, nutrition and growth of mungbean. Agronomy for Sustainable Development 28:273-280. https://link.springer.com/article/10.1051/agro:2008010

White PJ Brown PH (2010). Plant nutrition for sustainable development and global health. Annals of Botany 105:10731080. https://doi.org/10.1093/aob/mcq085

Xue Z-C, Gao H-Y, Zhang L-T (2013). Effects of cadmium on growth, photosynthetic rate and chlorophyll content in leaves of soybean seedlings. Biologia Plantarum 57:587-590. https://link.springer.com/article/10.1007/s10535013-0318-0

Yan B, Dai Q, Liu X, Huang S, Wang Z (1996). Flooding-induced membrane damage, lipid oxidation and activated oxygen generation in corn leaves. Plant Soil 179:261-268. https://link.springer.com/article/10.1007/BF00009336

Yang QW, Lan CY, Wang HB, Zhuang P, Shu WS (2006). Cadmium in soil-rice system and health risk associated with the use of untreated mining wastewater for irrigation in Lechang, China. Agriculture and Water Management 84:147-152.

Yang XE, Long XX, Ye HB, He ZL, Calvert DV, Stoffella PJ (2004). Cadmium tolerance and hyperaccumulation in a new Zn-hyperaccumulating plant species (Sedum alfredii Hance). Plant and Soil 259:181-189. https://doi.org/10.1016/j.agwat.2006.01.005

Yang ZM, Wang J, Wang SH, Xu LL (2003). Salicylic acid-induced aluminum tolerance by modulation of citrate efflux from roots of Cassia tora L. Planta 217:168-174. https://link.springer.com/article/10.1007/s00425-003-0980-0
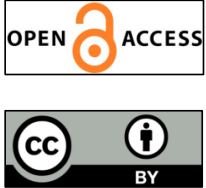

The journal offers free, immediate, and unrestricted access to peer-reviewed research and scholarly work. Users are allowed to read, download, copy, distribute, print, search, or link to the full texts of the articles, or use them for any other lawful purpose, without asking prior permission from the publisher or the author.

License - Articles published in Notulae Botanicae Horti Agrobotanici Cluj-Napoca are Open-Access, distributed under the terms and conditions of the Creative Commons Attribution (CC BY 4.0) License. (c) Articles by the authors; UASVM, Cluj-Napoca, Romania. The journal allows the author(s) to hold the copyright/to retain publishing rights without restriction. 